U. S. DEPARTMENT OF AGRICULTURE, BUREAU OF PLANT INDUSTRY - BULLETIN NO, 178.

\title{
IMPROVEMENT OF THE WHEA'T CROP IN CALIFORNIA.
}

BY

\author{
HENRY F. BLANCHARD,
}

Assistant Agronomist, Office of Grain Investigations.

ISSUED JUNe 1, 1910.

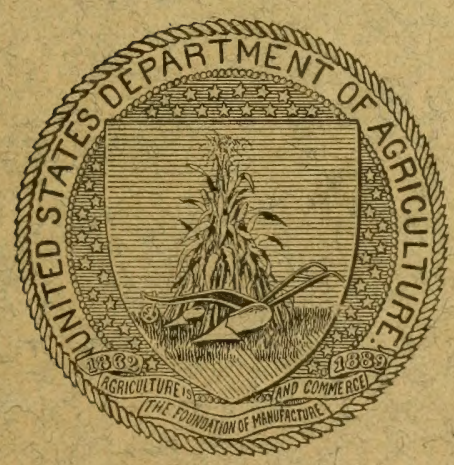

WASHINGTON:

GOVERNMENT PRINTING OFFICE.

1910. 


$$
\text { 웅 }
$$





\section{U. S. DEPARTMENT OF AGRICULTURE,}

BUREAU OF PLANT INDUSTRY_BULLETIN N0. 178.

B. T. GALLOWAY, Chief of Bureau.

\section{IMPROVEMENT OF THE WHEAT CROP IN CALIFORNIA.}

BY

HENRY F. BLANCHARD, Assistant Agronomist, Office of Grain Investigations.

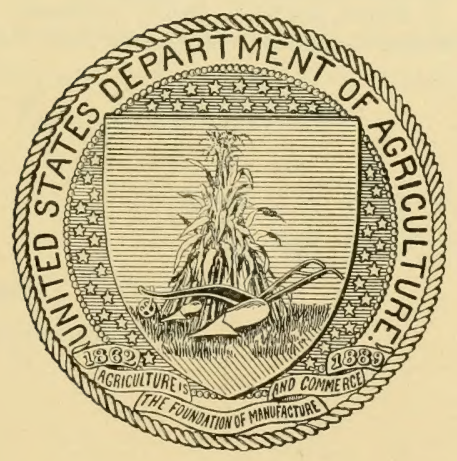

WASHINGTON :

GOVERNMENT PRINTING OFFICE.

1910. 


\section{BUREAU OF PLANT INDUSTRY.}

Chief of Bureau, Beverly T. Galloway. Assistant Chief of Bureau, G. HAROLD POWELL. Editor, J. E. ROCKWELL.

Chief Clerk, JAMES E. Jones.

Grain Investigations.

SCIENTIFIC STAFF.

Mark Alfred Carleton, Cerealist in Charge.

W. M. Jardine, C. R. Ball, H. B. Derr, and C. W. Warburton, Agronomists.

E. C. Johnson, Pathologist.

C. E. Chambliss, Expert.

John F. Ross, Farm Superintendent.

H. F. Blanchard and H. J. C. Umberger, A ssistant Agronomists.

F. R. Babcock, V. L. Cory, F. D. Farrell, and W. G. Shelley, Assistants.

E. L. Adams, L. C. Burnett, Manley Champlin, J. M. Jenkins, A. A. Potter, and Cecil Salmon, Special Agents.

178

2

\section{JUN 221910}

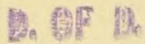




\section{LETTER OF TRANSMITTAL.}

U. S. Department of Agriculture,

Bureau of Plant Industry,

Office of the Chief,

Washington, D. C., February 28, 1910.

SIR: I have the honor to transmit herewith a paper entitled "Improvement of the Wheat Crop in California," by Mr. Henry F. Blanchard, Assistant Agronomist in the Office of Grain Investigations, and recommend its publication as Bulletin No. 178 of the series of this Bureau.

For many years there has been a steady deterioration in the wheat crop of California, due to two general causes, (1) bad methods in farm practice and (2) a lack of varieties adapted to that region. The Office of Grain Investigations, of this Bureau, has investigated these conditions for about five years, during a part of which time the work has been in cooperation with the state experiment station at Berkeley, Cal. Besides observations on many farms and other investigations, experiments in methods of cultivation and adaptation of varieties have been conducted in detail at two points, Davis and Modesto. The accompanying paper gives briefly some of the results of investigations, to date, along these lines.

Respectfully,

G. H. PowelL, Acting Chief of Bureau.

Hon. James WiLson, Secretary of Agriculture. 



\section{CONTENTS.}

Common methods of cultivation unsatisfactory ...................... 8

Original methods of cultivation.................................. 8

Changes from original methods.............................. 8

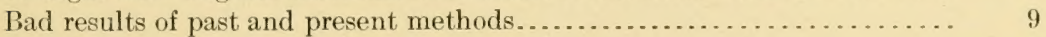

Soil low in humus and nitrates.......................... 9

Soil foul with weeds................................. 10

Requirements for the production of profitable crops.................. 10

Smaller farms and personal supervision by owners.............. 10

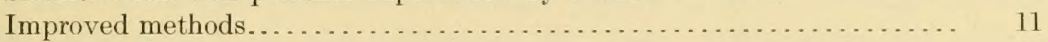

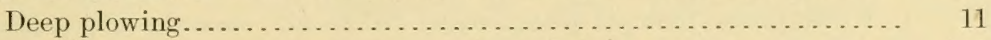

Addition of humus and nitrogen to the soil................ 12

Crops to be used as green manure..................... 13

Time and method of handling....................... 13

Effect of deep plowing and green manuring................. 15

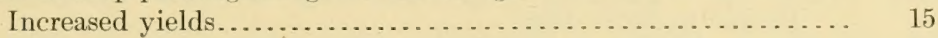

Increased profits.................................... 17

Cleaning the land of weeds................................... 18

Development of better varieties of wheat........................ . 19

Variety tests in California............................... 19

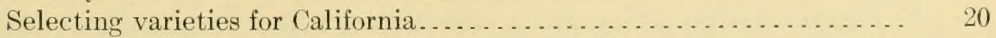

Climate and soil .................................. 20

Habit of growth .................................. 21

Nonshattering habit............................... 21

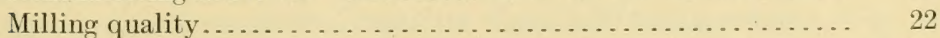

Other requisites.................................. 22

Seed improvement by the grower ........................ 23

Small compared with large seed ..................... 23

The seed plat.................................. 23

Two new varieties of wheat adapted to California conditions............ 24

The Chul variety............................................ 24

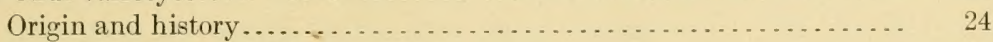

Introduction into California.............................. 25

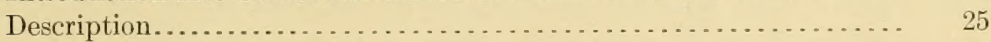

Yields obtained............................................. 25

Milling quality ........................................ 26

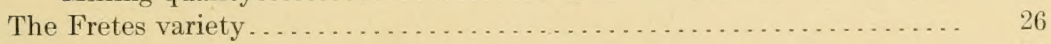

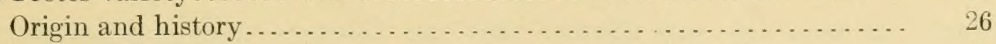

Description........................................... 27

Yields obtained ........................................ 27

Milling quality .......................................... 28

Pure seed of the Chul and Fretes varieties................... 29

Protein content as affected by time of seeding. . . . . . . . . . . . . . . 29

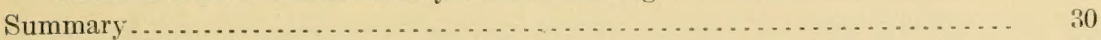

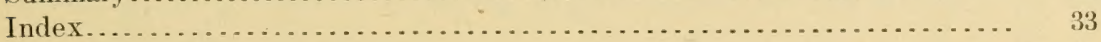




\section{ILLUSTRATIONS.}

FIG. 1. Wheat plants from six plats treated differently, showing comparative development. . . . . . . . . . . . . . . . . . . . . . . . .

2. Wheat growing on plat which has been continuously seeded to the

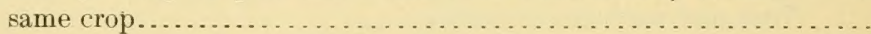

3. Wheat growing on plat on which Canadian field peas were grown and

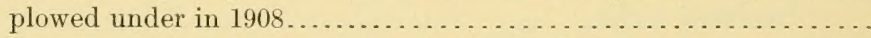

4. Wheat growing on plat on which rye and vetch were grown and plowed

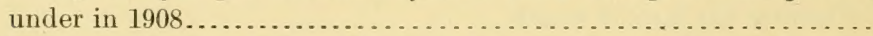

5. Wheat growing on plat on which rye was grown and plowed under

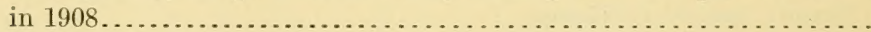

6. Representative plants of six varieties of wheat from uniform plats planted November 21, 1908, at Modesto, Cal., showing their com-

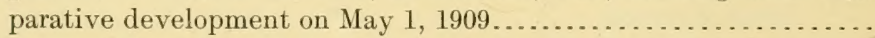

7. Representative plants of six additional varieties of wheat from uniform plats planted November 21, 1908, at Modesto, Cal., showing their comparative development on May 1, 1909.................

8. Chul wheat (G. I. No. 2227) growing at Modesto, Cal., in 1909 ... . . .

9. Fretes wheat (G. I. No. 1596) growing at Modesto, Cal., in 1909.....

10. White Australian wheat (G. I. No. 3019) growing at Modesto, Cal.,

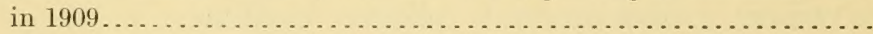

Page.

12

13

14

15

16

21

22

24

178 


\section{IMPROVEMENT OF THE WHEAT CROP IN CALIFORNIA.}

\section{INTRODUCTION.}

An impression exists among many California farmers that the soil will no longer produce profitable yields of good milling wheats. This impression is strengthened by two well-recognized facts: (1) That under past and present methods of wheat culture the soil is failing in many localities to produce as large crops as heretofore, and (2) that the Australian and Club varieties, the most widely grown California wheats, are extremely starchy. As only these very starchy varieties have been extensively grown, it has become necessary for the millers to import large quantities of Turkey wheat from the Middle West to blend with the California wheats.

In order to discover varieties better adapted to California needs than those commonly grown, the Office of Grain Investigations of the Bureau of Plant Industry has for a number of years conducted extensive tests of wheat varieties, including many of foreign origin. In this way it was hoped to improve the California wheat crop in both yield and milling quality. As improved methods of cultivation are necessary also to obtain profitable yields of nitrogenous wheats, an effort has been made to determine the effect of deep plowing and the addition of humus to the soil in the form of winter green-manure crops. The time of plowing, the conservation of moisture, and the eradication of weeds have also been considered. If the State is to continue the profitable use of its grain lands and derive from them the largest possible return, it is quite necessary that there be an improvement in the general practices of cultivation and in the varieties grown.

The investigations covered by this report are in general based upon results obtained and observations made during a number of years, a part of the time in cooperation with the California Agricultural Experiment Station. An effort has been made to so correlate the results and observations that they will be of benefit to the California grain grower in effecting improvement in soil fertility, in the

32912-Bul. 178-10-2 
yield of wheat to the acre, and in the milling quality of the grain produced.

The investigations carried on thus far are simply the foundation for a more extensive work in the future. It is necessary in order to find a few desirable varieties that a large number be first grown in small areas and compared with the commonly grown varieties. The results obtained in this way indicate which varieties may be submitted to practical tests directly with the farmers.

\section{COMMON METHODS OF CULTIVATION UNSATISFACTORY.}

The cultivation methors still commonly practiced by many of the farmers of California have been brought about by the conditions existing about 1860 , when it was first discovered that wheat could be grown as a profitable crop. These conditions were as follows: Fertile virgin soil, large level valleys facilitating extensive cultivation, a growing season extending from November to June, and a period of rainfall extending over the growing season, with comparatively high temperatures during the winter months and low temperatures during the spring months. The methods are generally very simple and very crude. They consist in the continuous cropping of wheat and barley upon soil which receives only a very shallow cultivation. The farmer is removing the plant food from the soil without the addition of anything to take its place. This is resulting in many localities in a depleted condition of the soil, and profitable crops of wheat are no longer grown.

ORIGINAL METHODS OF CULTIVATION.

The first grain producers of California attempted to crop as large an acreage as possible at a minimum cost. In order to do this, at that time all that was necessary was very shallow plowing (3 or 4 inches in depth), broadcasting the seed, and harrowing it into the soil. This was continued from year to year and fairly good crops were produced for a while. The header and stationary thrasher were used in harvesting the grain. Very little attempt was made on the part of the producer to secure pure seed of the varieties grown or to practice the careful grading of wheat, using only the largest and best kernels for seed. In fact, very little attention was given to the seed used. In many instances the farmer used the poorest grade of grain that he had grown the previous year.

\section{CHANGES FROM ORIGINAL METHODS.}

Since the earlier period of wheat production in California some changes have taken place or are now in progress. The most important of these are the replacing of the header and stationary thrasher by 
the combined harvester and the beginning of the practice of summerfallowing the land.

The change to the combined harvester', about 1880 , was due largely to labor conditions existing at that time. It was difficult to secure enough men to properly handle the grain, and the methods of harvesting were unsatisfactory. The climatic conditions, as well as the general contour of the land, were found to be favorable to the use of the combined harvester. This machine reduces to the minimum the number of men employed and at the same time utilizes the power of mules and traction engines.

Proper methods of summer-fallowing the land are not yet generally practiced. Summer-fallowing became necessary on account of the foul condition of the soil which had been produced by continuous cropping to wheat. The use of the combined harvester, however, has partly offset the cleaning effect of the fallow. This method of tillage is beneficial, especially when it precedes a particularly dry season, as in this way a large amount of the rainfall for two years is retained in the soil. At first it was found necessary to summer-fallow the land every third year only, but later, every second year.

Other changes which have been taking place during recent rears are the reduction in size of a few grain farms and an increase in the depth of plowing on the part of some farmers. These changes, how"ver, occur in individual instances only and are not general in their nature.

\section{BAD RESUlts OF PAST AND PRESENT METHODS.}

We now have in many sections of California, as a result of the common methods of wheat culture, a soil which refuses to produce profitable crops of the commonly grown varieties of wheat. The general practice of single cropping has depleted the soil in humus and nitrates and made it very foul with weeds.

\section{Soll Low in Humus and Nitrates.}

There are large sections of California which have been sown in wheat and barley under the commonly practiced methods for the past thirty or forty years. These crops rapidly deplete the soil in humus and nitrates. Ifumus is the decaying organic material which gives body to the soil and is essential in retaining the soil moisture. It also affects the temperature of the soil, producing somewhat higher temperatures in winter and lower temperatures in summer, according to Wollny, as cited by Hilgard. ${ }^{a}$ The nitrates of the soil are very essential in the production of wheat, as they form an important part of the necessary plant food. A soil low in nitrates usually tends to 
decrease the nitrogen content of wheat grown upon it. On soils low in humus and nitrates there is also a correspondingly low yield of wheat.

\section{Sorl Foul with Weeds.}

The weed problem is not of minor importance. In fact, when passing through ('alifornia grain fields and finding that large areas are badly infested with weeds one is impressed with the effect that they must have upon the yields of wheat. This weedy condition is due largely to the common methods of harvesting and cultivating. In many localities the soil has become so weedy that even with the best methods of summer fallowing commonly practiced by the farmer it is impossible to prevent large damage to the crops. The weeds in many instances crowd out the wheat plants by outgrowing them during the winter months.

\section{REQUIREMIENTS FOR THE PRODUCTION OF PROFITABLE CROPS.}

In order to produce profitable crops of wheat on the worn-out grain lands of California the past and even the present methods of production must in a large measure give way to methods which will produce better results in the future. This to a small degree has already taken place in some sections. There are also large areas of the State upon which wheat has not been grown for as long a period of time as on those sections first farmed. However, these are being rapidly reduced to the same depleted condition on account of the unscientific practices in use.

In some localities where the soil now fails to produce profitable grain crops it has been possible to grow other crops on the same land. In general, such instances are confined to the areas upon which water can be applied. Alfalfa and fruit usually do well in such sections. There are, however, large areas to which water can not be readily applied, and these will no doubt be used for the production of grain for many years to come.

In order to produce crops of grain on such lands it not only becomes necessary to introduce new varieties or improved forms of those now grown, but a change in the actual farming methods for grain as they now exist is absolutely essential. The present methods sufficed for a time, and temporary profits from the soil resulted. It has been comparatively easy to produce crops from a fertile soil without taking into account the effect of such methods upon the soil. It will require much more skill and effort to return the soil to a condition in which good crops of wheat may again be produced.

SMALLER FARMS AND PERSONAL SUPERVISION BY OWNERS.

In the pioneer days of California the interior valleys were not considered of much value for the production of crops on account of 
the small amount of rainfall. At that time certain companies were enabled to secure large tracts of this land at a nominal price. These companies discovered that this land would produce good yields of grain and it was cropped on a very large seale. Since that time there has been a gradual breaking up of these large farms into smaller ones. However, there are still too many large ones to make probable the general use of improved methods of grain production. Until the farms are so reduced in size that they may be properly handled we may look for continued low production and further depletion in the soil fertility of the wheat lands.

Another feature of much of the grain production in (alifornia is the practice of renting the lands from year to year to men who are not interested in the building up of the soil. The desire of the tenant is to get all that is possible out of the land at the least expense to himself during the time which he holds it. As long as this condition exists there will be a continued decrease in the value of the wheat lands. The remedy for this is the direct supervision by the owner of the methods of cultivation and cropping. He has a real interest in the future condition of his soil and will undoubtedly give it better attention than the tenant who is interested only in the crop he produces each year.

\section{IMPROVED METHODS.}

Improvement in the methods of wheat culture is essential to the production of more profitable crops. These improvements include the practice of deeper plowing, the increase of soil humus and nitrates by turning under green-manure crops, and the cleaning of the land of weeds by better methods of cultivation.

\section{Deep Plowing.}

At the present time we can not place too much stress upon the importance of deep plowing. The few inches of soil at the surface have been skimmed for so long that they are practically devoid of plant food in available form. For this reason alone it becomes necessary to turn up fresh soil. This will necessitate cutting below that stratum of soil commonly known as the "plow pan," which has been formed by the practice of plowing year after year at the same depth. In many localities plowing at a depth of from 8 to 12 inches is advisable. Unless green-manure crops are to be turned under, this depth should be reached by a gradual increase in depth for two or three years. By this gradual increase in depth the subsoil will become properly mixed with the surface soil.

Deep plowing requires more power than is needed for the ordinary method, and the first deep plowing is more difficult than subsequent 
plowings. This is due largely to a more or less packed condition of the subsoil. Deep plowing should be clone in the early spring while there is still sufficient moisture in the soil. It should not be done while the soil is either too wet or too dry. While the benefits derived from deep plowing may not be so erident the first season, the results obtained are of permanent character. The subsoil is benefited by direct contact with the air and other climatic influences, and the

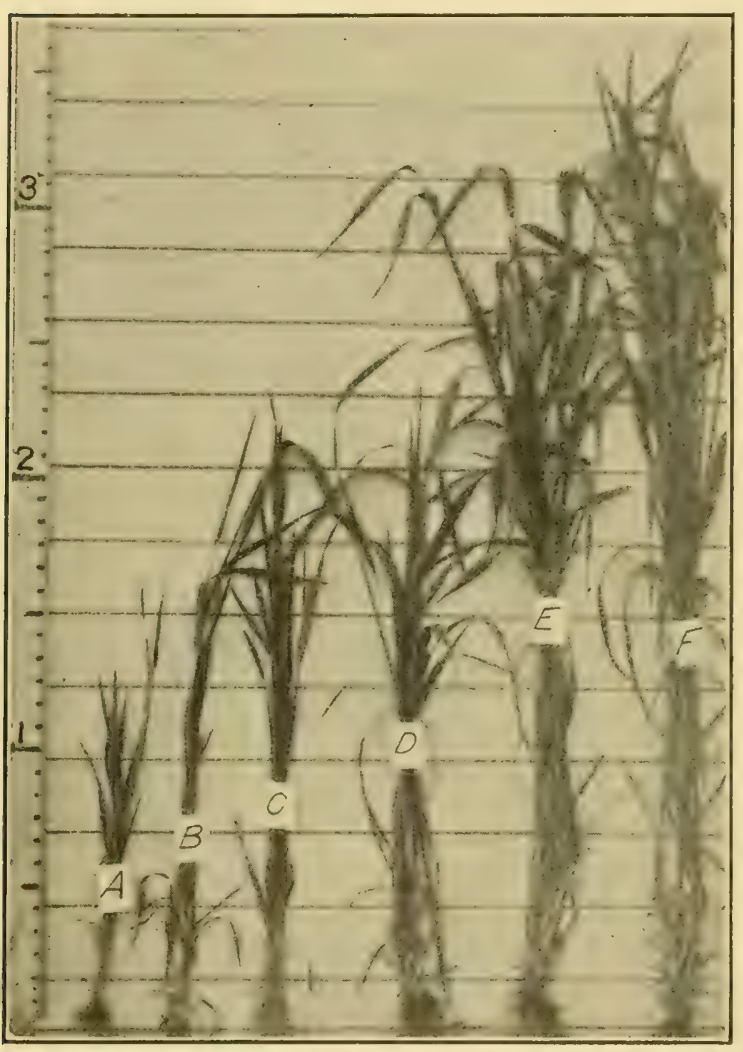

Fig. 1.-Wheat plants from six plats treated differently, showing comparative development: $\boldsymbol{A}$, From plat continuously seeded to wheat; $B$, from plat barefallowed in 1008; $C$, from plat upon which horse heans were grown and plowed under in 190s; $D$, from plat upon which Canadian field peas were grown and plowed under in 1908; $E$, from plat upon which rye and vetch were grown and plowed under in 1908; $F$, from plat upon which rye was grown and plowed under in 1908. effects of deep plowing will be more noticeable the second and succeeding years.

Andition of Humus AND Nitrogen to the Soll.

As already stated the soil of California grain lands is low in humus. In order to add humus to the soil green-manure crops must be grown and plowed under. This is necessary not only in order that land very low in humus be again placed in good condition, but also that lands in which humus is now fairly plentiful be retained in good shape (fig. 1). Owing to a tendency of very light sandy soil to shift during heavy winds, deep) plowing may be detrimental at first on such soils. This soil shifting may, howerer, be reduced to a minimum by the addition of humus, which will give it boty and make possible the practice of deep plowing without injury.

$17 \mathrm{~s}$ 
('anadian field peas and Abruzzes rye do very well as green-manure crops in the valley sections of the State. Tnder favorable conditions in the Sacramento Valley peas alone have given very goonl results when seeded at the rate of so pounds to the acre. (On the lighter soils of the Sam Joaquin Valley peas do not make as rank a growtl as in the Sacramento Valley. For this reason it is sugresested that peas and rye be grown together, the rye to be sown at the rate of 40 pounds and the peas 50 pounds to the acre. The rye and pea vines will add humus to the soil, while the nodules on the roots of

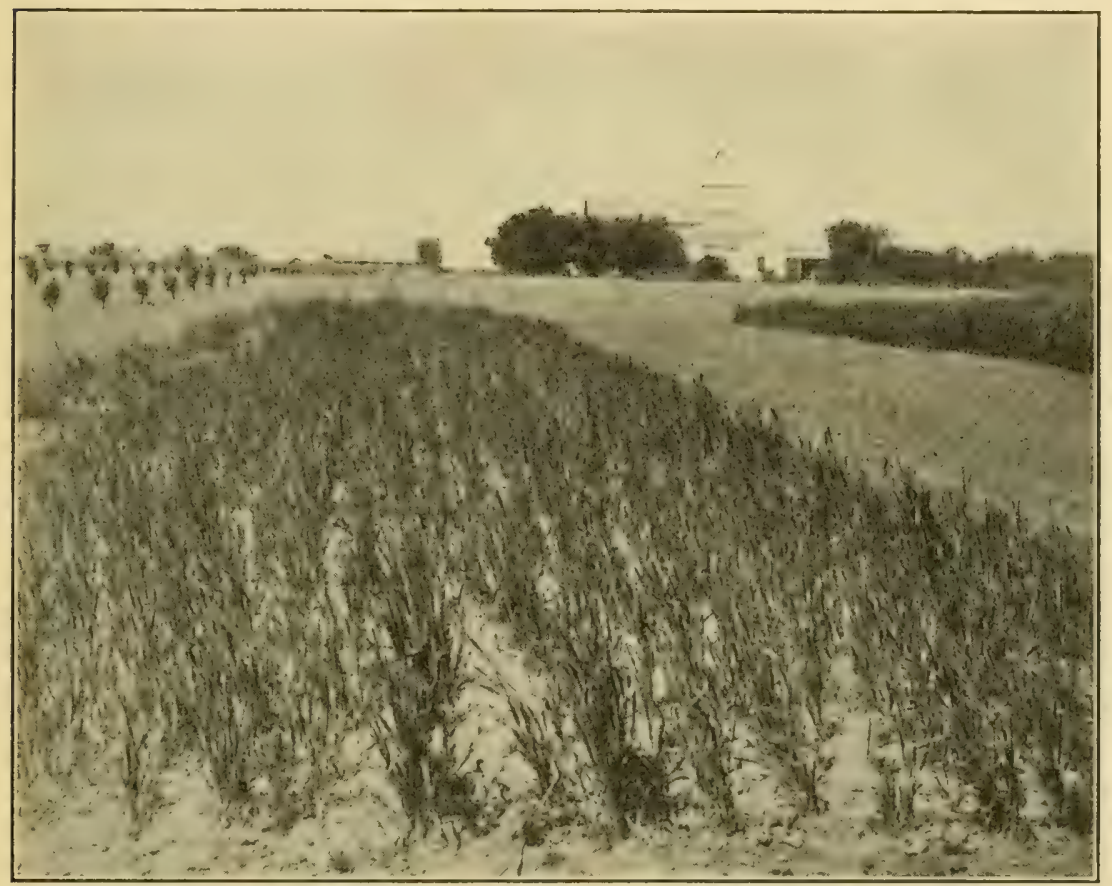

FiG. 2.-Wheat growing on plat which has been continuously seeded to the same crop. (See figure 1, A.)

the pea vines will transfer the nitrogen of the air to the soil in the form of nitrates. If rye and peas are to be grown separately, the rye should be sown at the rate of 70 pounds and the peas at the rate of 80 pounds to the acre.

TLME AND METHOD OF HANDLING.

Rye and peas for green manure must be grown as a winter crop. They should be planted as soon as it is possible to plow the land in the fall and should be turned under before the land is too dry for plowing in the spring. Usually there is sufficient moisture in the 
soil to allow the planting of green-manure crops by December 1 , though in some sections and in exceptional seasons the planting may be necessarily later. It is not advisable, however, to sow later than December 15, for unless the early spring rains are so delayed as to facilitate late plowing the green-manure crop will not be of much value. This crop should be turned under during early March before the soil is too dry for deep plowing. In other words, in order to give green-manure (rops the maximum period of growth it is necessary to sow as early as the ground can be worked in the fall and to turn under as late as possible in the spring.

The length of the growing period is regulated very largely by the

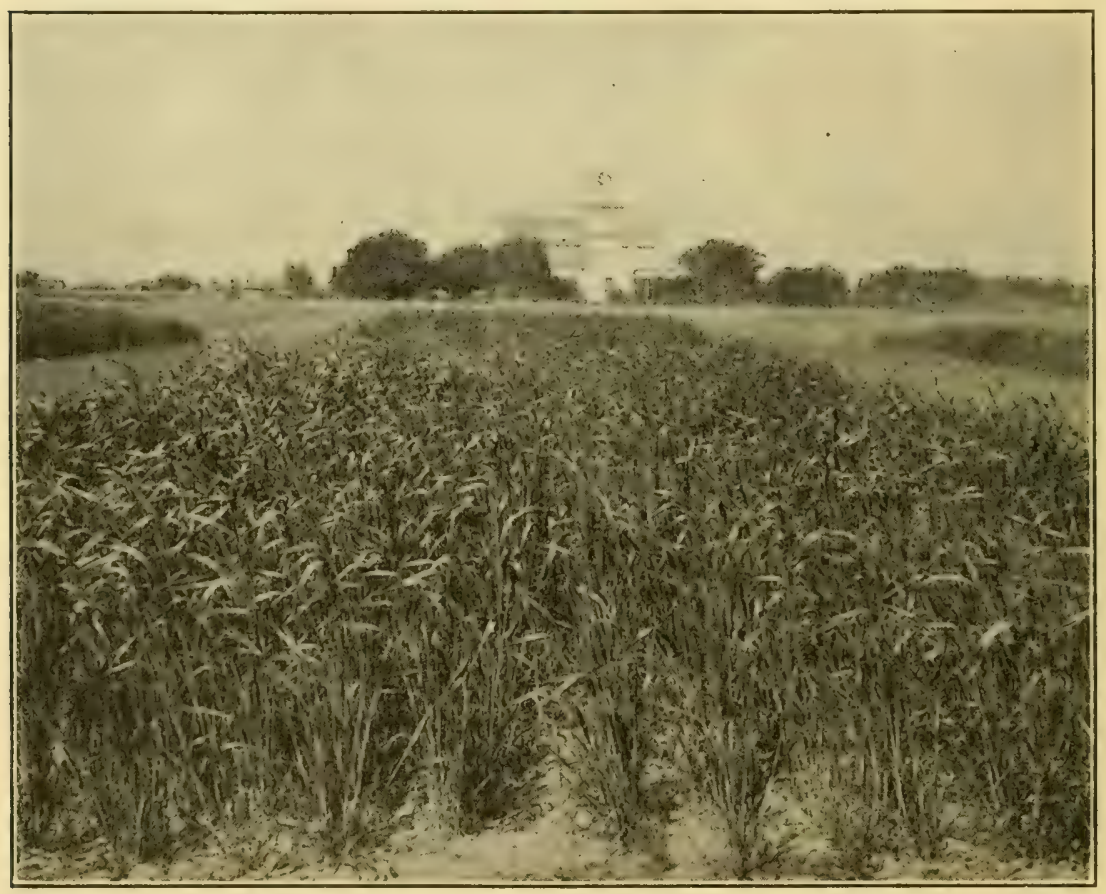

FIG. 3.-Wheat growing on plat on which Canadian field peas were grown and plowed under in 1908. (See figure $1, D$.)

length of the rainy season. The dry condition of the wheat fields in the fall permits a plowing of only 4 to 5 inches in depth when gretting the stubble land in shape for the early planting of greenmanurè crops. The stubble should be double-disked, where possible, immediately after the wheat crop is harvested. The disking prepares the land to retain the moisture already present and to receive the light precipitation coming during the fall months, thus putting it in shape for an early shallow plowing and a good seed bed. In the spring the land should be plowed deep in order to get 178 
the growing peas or rye well under, where they will readily decay, after which the soil should be well harrowed immediately.

Effect of Deep Plowing and Green Manuring.

The effect of deep plowing and green-manure crops upon the yield of wheat, as determined by observation and actual experiment (see figs. 2, 3, 4, and 5), is shown in Table I, these yields being obtained at Modesto, Cal., in 1909.

INCREASED YIELDS.

While the results indicated are not entirely conclusive, for the reason that they are not based upon trials extending over a long

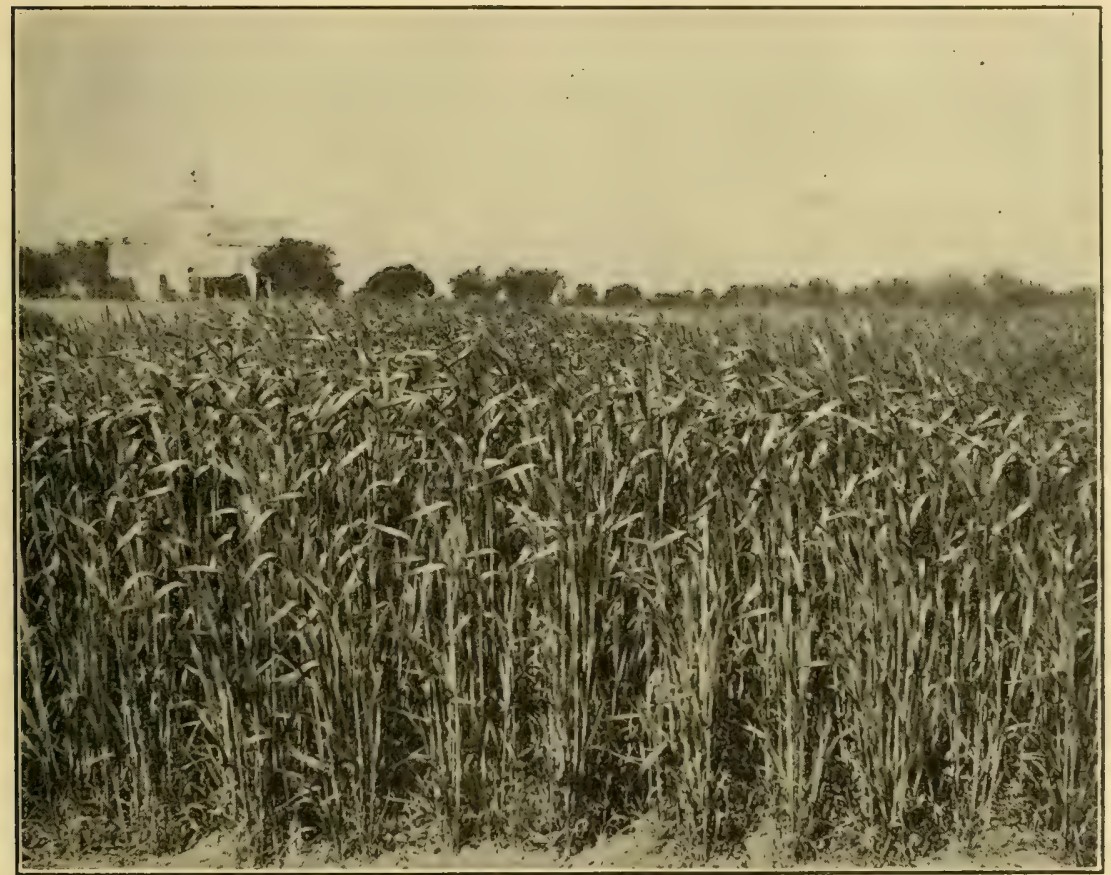

FIG. 4.-Wheat growing on plat on which rye and vetch were grown and plowed under in 1908 . (See figure $1, E$.)

series of years, they give an idea of what may be accomplished by the deep plowing under of green-manure crops. $\Lambda$ s indicated, horse beans used as green manure appear to give better results than peas. However, they have a very thick and heavy stalk, and an enormous quantity of seed is required on account of their habit of growing a single stalk from each seed. They are not recommended in the place of peas, which will give better results in combination with rye as a green-manure crop. 
TABLE I.-Effect of deep plowing and green-manure crops on the yield of wheat at Modesto, Cal., 1909.

\begin{tabular}{|c|c|c|c|}
\hline $\begin{array}{l}\text { No. } \\
\text { of } \\
\text { plat. }\end{array}$ & Preceding treatment or crop. & $\begin{array}{l}\text { Yield } \\
\text { per } \\
\text { acre. }\end{array}$ & $\begin{array}{c}\text { Weight } \\
\text { per } \\
\text { bushel. }\end{array}$ \\
\hline $\begin{array}{l}1 \\
2 \\
3 \\
4 \\
5 \\
6\end{array}$ & 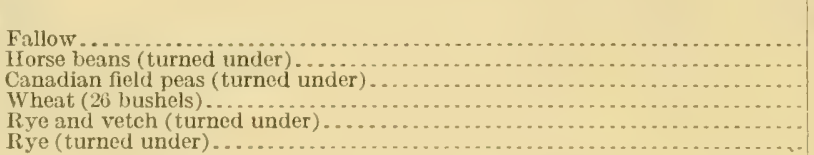 & $\begin{array}{r}\text { Bushels. } \\
28.00 \\
35.33 \\
33.66 \\
15.66 \\
50.66 \\
51.33\end{array}$ & $\begin{array}{r}\text { Pounds. } \\
61 \\
61 \\
60 \\
60 \\
60 \\
61\end{array}$ \\
\hline
\end{tabular}

The cultivation of the plats indicated in the table was as follows: In the fall of 1907 all of the plats were laid out on summer-fallow

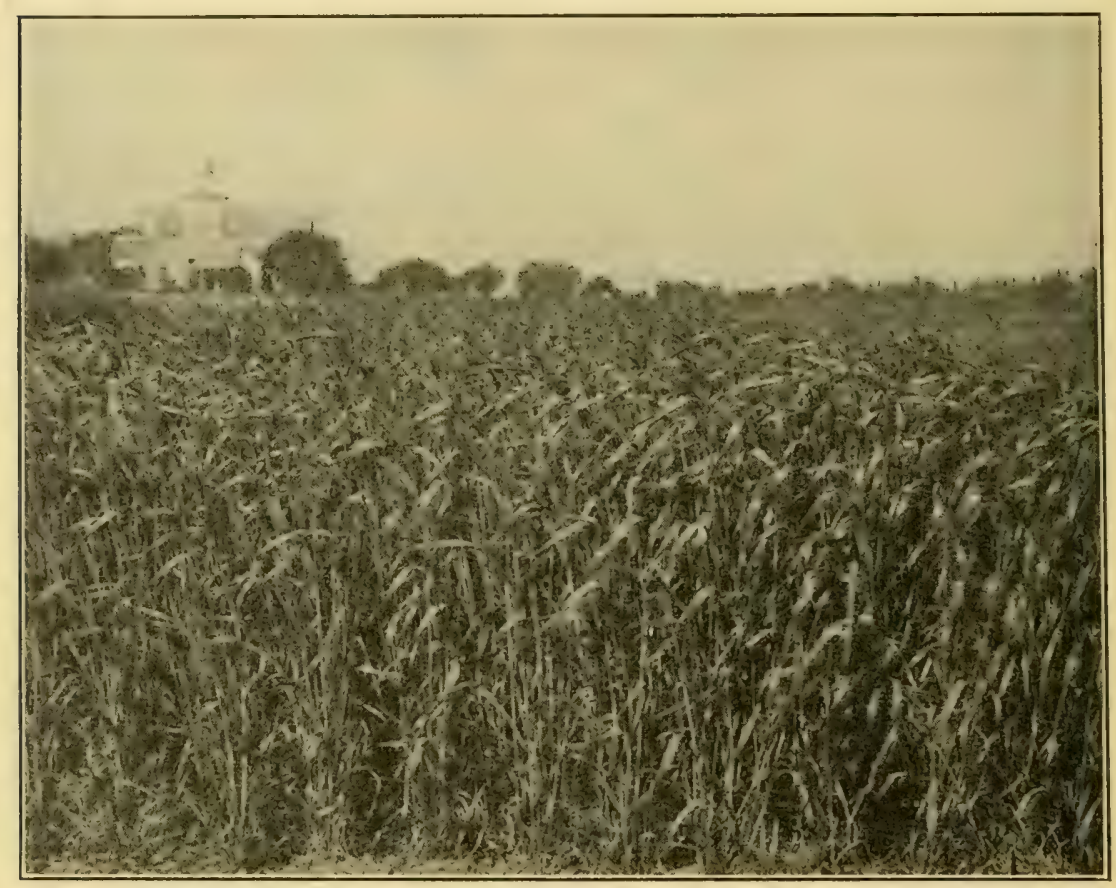

Fig. 5.-Wheat growing on plat on which rye was grown and plowed under in 1908 . (See figure 1, F.)

land and all were plowed to a depth of 6 inches and harrowed. Plat 1 was allowed to remain fallow. Plat 4 was sown to wheat. Plats $2,3,5$, and 6 were sown, as indicated, to horse beans, Canadian field peas, rye and vetch, and rye alone. The vetch in plat 5 made a very poor stand, while the horse beans and peas made a fairly good stand. The stand of rye was excellent.

In March, 1908, plats 1, 2, 3, 5, and 6 were plowed 8 inches deep, harrowed, and kept clean throughout the summer and fall. Plat 4, 
which yielded at the rate of 26 bushels of wheat to the acre, was double-disked immediately after the wheat was taken off.

The first of December, 1908, all plats were plowed to a depth of 5 inches and sown to wheat. The resulting yields are given in Table I. In two years' time the plat continuously seeded to wheat has produced 41 bushels of wheat. However, the first year's yield, 26 bushels, was produced after summer fallow and the second year's yield, 15.66 bushels, shows a decrease of nearly half. It is quite probable that the third year will give a very low yield and that in a series of five years the quantity of wheat produced from continuously seeded plats would be much smaller than from the other methods of cultivation.

It follows, then, from this experiment, that deeply plowed summer fallow will give much better yields than shallow-plowed, continuously cropped land. Plats 1, 2, 3, 5, and 6 were all plowed at the same depth, and the last four were fallowed also after turning under the green crops. The yields indicate that the addition of organic matter (humus) to the soil is beneficial in increasing the production of crops and that this increase is proportional to the quantity rather than the quality or kind of organic matter added.

\section{INCREASED PROFITS.}

The yields shown in Table I were obtained in plat work, where the varieties received the best possible attention, thus giving higher yields than would have been probable under field practice. In our estimate of the increase in profits brought about by thorough methods of cultivation, the yields are estimated at two-thirds the value given in the table.

The estimate made of increase in net profits is based largely upon observation of the general cost of farm work in the State. It may not be absolutely accurate in every particular, but it serves well in bringing out a comparison of the common methods of cultivation employed with the more intensive methods suggested in this paper.

A pproximate cost of cultivation per acre by the common method.

First plowing $(5$ inches deep)......................... $\$ 1.25$

Second plowing $(5$ inches deep) .......................... 1.25

Two harrowings................................... . 20

2. 70

Approximate cost of cultivation per acre by the improved method.

Double-disking stubble............................. $\$ 0.50$

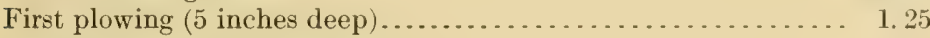

Second plowing (8 inches deep)....................... 2.00

Third plowing (4 inches deep) ....................... 1.25

Three harrowings................................... . 30

Rye seed for green manure. ....................... 2.00 
The approximate cost of cultivation by the common method is $\$ 2.70$ per acre, as compared with $\$ 7.30$ per acre by the improved method suggested, which gives an increased cost of $\$ 4.60$ per acre for better tillage. As shown in Table I, we have almost doubled the yield per acre by the improved methods. Suppose the yields given in the table were reduced to two-thirds their value, as previously suggested. We still have wheat, following ordinary methods of bare fallow, yielding at the rate of 19 bushels per acre, while wheat following deep plowing and rye as a green-manure crop yields at the rate of 34 bushels per acre. With wheat at $\$ 1$ a bushel we have at a cost of $\$ 2.70$ per acre produced $\$ 19$ (not deducting cost of harvest, etc.). By better methods at a cost of $\$ 7.30$ per acre we have produced $\$ 34$ (not deducting cost of harvest, etc.). This gives an approximate increase of net profit of $\$ 10.40$ per acre in favor of the better method of tillage.

Cleaning the Land of Weeds.

The problem of cleaning the land of weeds reduces itself to systematic cultivation and the production of rapidly growing varieties, especially as concerns their early development. Where cultivated crops are grown it is readily understood that the problem of getting rid of weeds is not so difficult as with wheat crops. Results obtained lead us to suggest that the following method of cultivation, if rigidly enforced, will help in a large measure to reduce the weeds in wheat fields:

(1) Thoroughly double-disk the land as soon as possible after harvest, thus stirring the surface, breaking up the stubble, and covering the weed seeds. Then allow the land to stand until the weed seeds at the surface have had a chance to germinate after the first rains.

(2) As soon as the weed seeds are well germinated, plow the land to a depth of 4 or 5 inches and harrow well. This should be done, if possible, not later than December 15.

(3) Between March 1 and 15, plow to a depth of from 8 to 12 inches. This exposes the weed seeds not turned up by the first plowing. Harrow the surface thoroughly immediately after plowing. Whether a summer crop is grown or the land is allowed to lie fallow it should be kept well cultivated and free from weeds.

(4) In November, plow to a depth of from 4 to 5 inches and sow the wheat about 2 inches deep.

(5) Just before the grain appears through the surface the land should be thoroughly double-harrowed in order to kill all weeds which have germinated following the seeding of the wheat.

(6) The variety of wheat grown should make a rapid, erect, early growth in order that it may keep ahead of and choke out all the young weeds which are not killed by the final harrowing. (Our 
investigations tend to prove that the flat-growing types of true winter wheat will not succeed in the valley soils of California, especially in their present condition of weediness.)

(7) The young grain should be thoroughly harrowed as soon as the ground is dry enough in the early spring, thus covering all of the young weeds which have started during the rainy season.

\section{DEVELOPMENT OF BETTER VARIETIES OF WHEAT.}

The proper cultivation of the soil is essential to the production of good yields of all varieties of wheat. It does not follow, however, that every variety of wheat will give good yields even on fertile soil properly cultivated. This erroneous idea prevails among certain grain growers. The United States Department of Agriculture has tested hundreds of varieties of wheat in different sections of the country and has found that comparatively few of these varieties are adapted to the prevailing climatic and soil conditions of each section. Varieties which produce good yields in one section of the country are found to be absolute failures in other sections.

\section{Variety Tests in California.}

Although a large number of varieties of wheat have been tested in California by this Department during the past five years, very few of these are adapted to the climatic and soil conditions of this State. California presents such a variety of climates that a type of wheat which may give excellent results in one section of the State does poorly in another. Our investigations thus far are not of long enough duration to enable us to state definitely the variety of wheat best adapted to any particular locality of the State. However, the results indicate that for the localities in which tests have been made we have now varieties which are better adapted to the prevailing conditions than those commonly grown by the farmers. We are able, therefore, with a fair degree of certainty, to recommend varieties for a large portion of the State.

Table II presents a list of some of the varieties of wheat which have been grown in California in connection with the investigations of the Department. The average yields to the acre, the number of days required to reach maturity, and the fruiting period (the number of days between the time of blossoming and the time of ripening) are based upon the plat experiments continued for three years in the San Joaquin Valley. The results obtained from the same varieties when grown in the Sacramento Valley compare very favorably with those indicated in this table. A few of these varieties are proving to be well adapted to both the localities in which they have been grown. 
TABLE II.-Results of variety tests of wheat in the San Joaquin Valley, California.

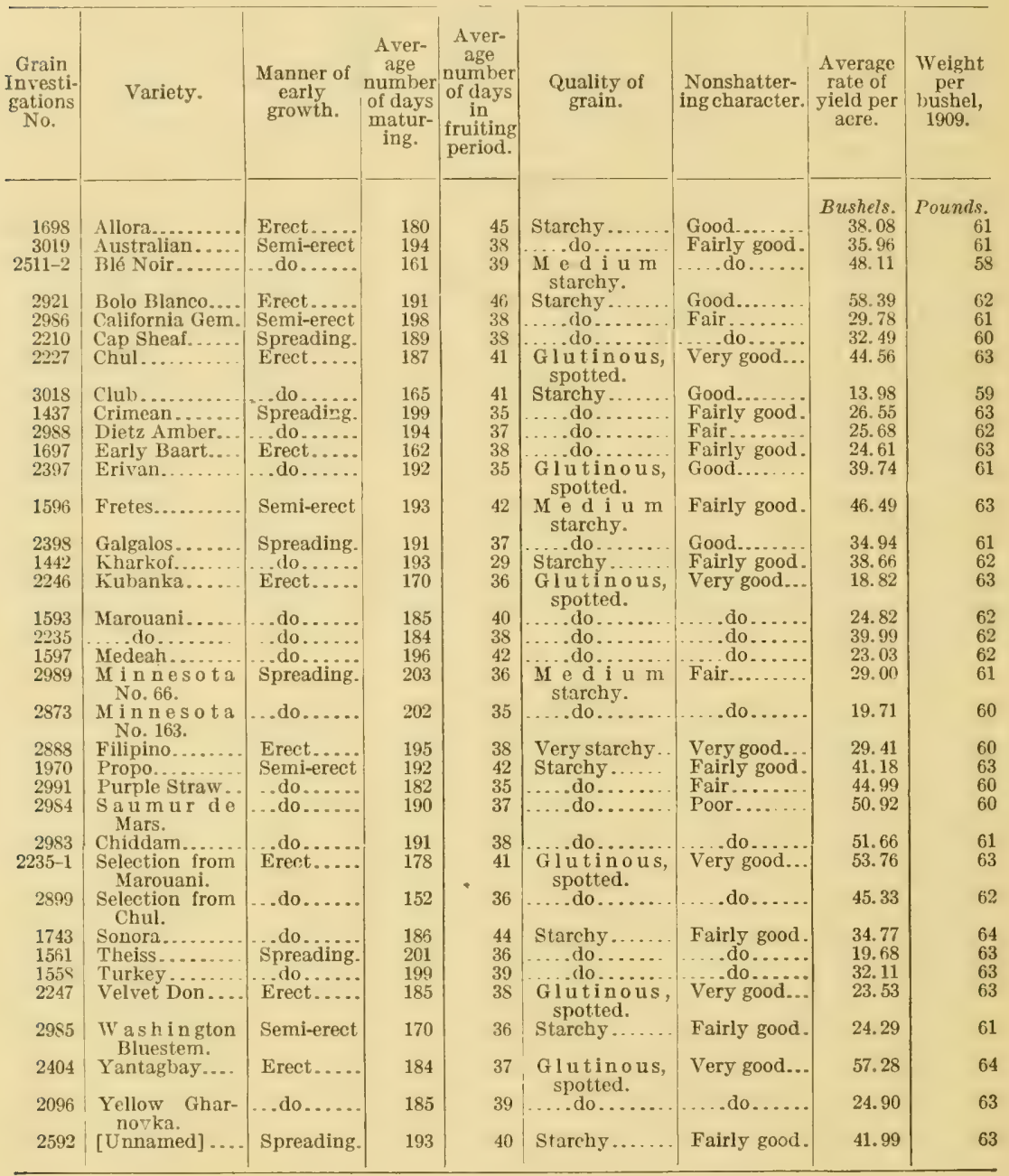

\section{Selecting Varieties for California.}

In selecting a variety of wheat which is better adapted to California conditions than the commonly grown varieties a number of matters must be taken into consideration.

CLIMATE AND SOIL.

The climate and soil of the locality in the State where the variety is to be tested are both important factors limiting the distribution of a variety. Some varieties will do well on light soils with a small amount of precipitation, while other varieties require a heavier soil with a larger amount of moisture. 
HABIT OF GROWTH.

The effect of the character of the early growth of a variety on its struggle with weeds is very important. (Figs. 6 and 7.) In the valley sections of California, where the temperature does not fall much below freezing during the winter months, varieties of vigorous, upright growth are needed in order that they may keep ahead of and choke out the weeds that start at this time. Varieties with a spreading habit of early growth may be adapted to mountain sections of high elevation, where there is a good deal of snow during the winter months and the temperature falls considerably below the freezing point, thus preventing weed growth until spring.

NONSHATTERING HABIT.

The nonshattering character of the head of wheat is a very important factor in some sections of California, as heavy windstorms often occur after the grain is ripe and before it is harvested. These winds shatter out a great

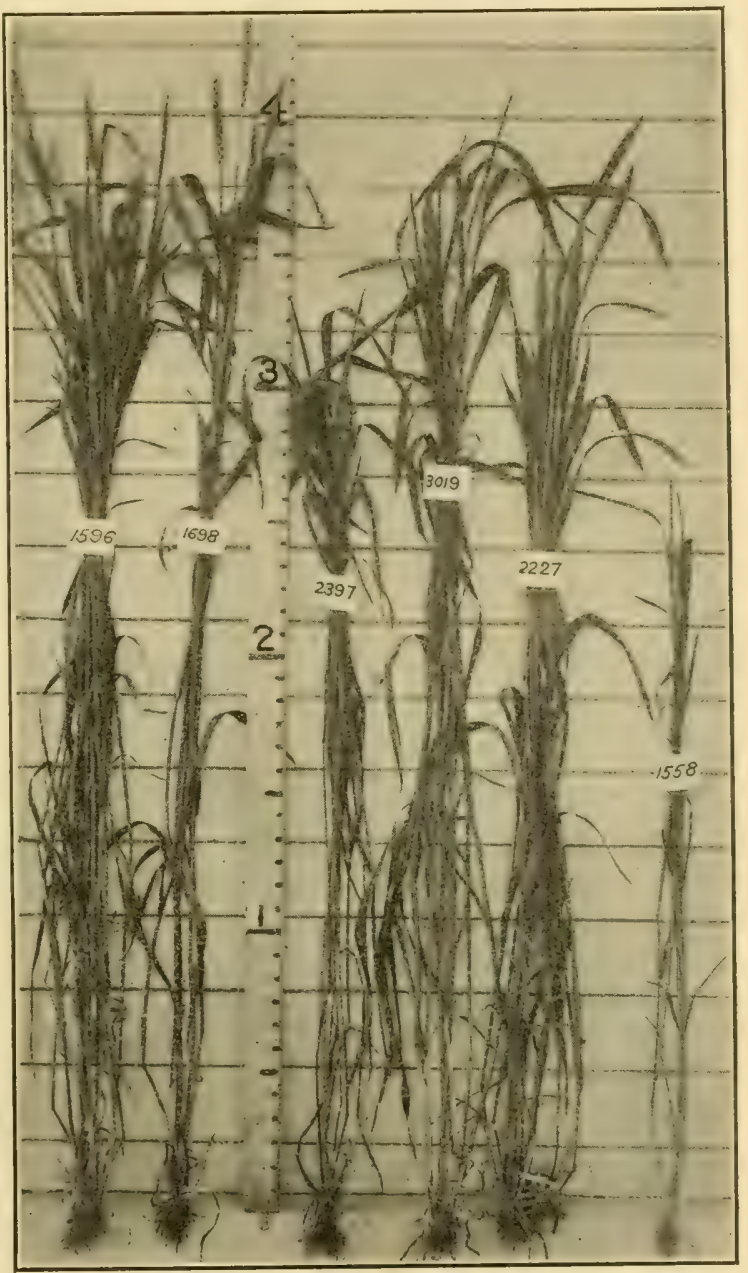

FIG. 6.-Representative plants of six varieties of wheat from uniform plats planted November 21, 1908, at Modesto, Cal., showing their comparative development on Мау 1, 1909: 1596, Fretes; 1698, Allora; 2397, Erivan; 3019, Australian; 2227, Chul; 1558, Turkey.

deal of grain from varieties which have not a very close-fitting chaff. The method of harvesting also has a tendency to shatter out much of the grain where it is not closely held by the chaff, owing to the fact that the crop is often allowed to stand for weeks after it is ripe. 
The milling quality is perhaps the most important factor to be considered in California. On account of the poor quality of the commonly grown varieties the California millers are unable to make good flour from these wheats when using them alone. Better milling wheat is

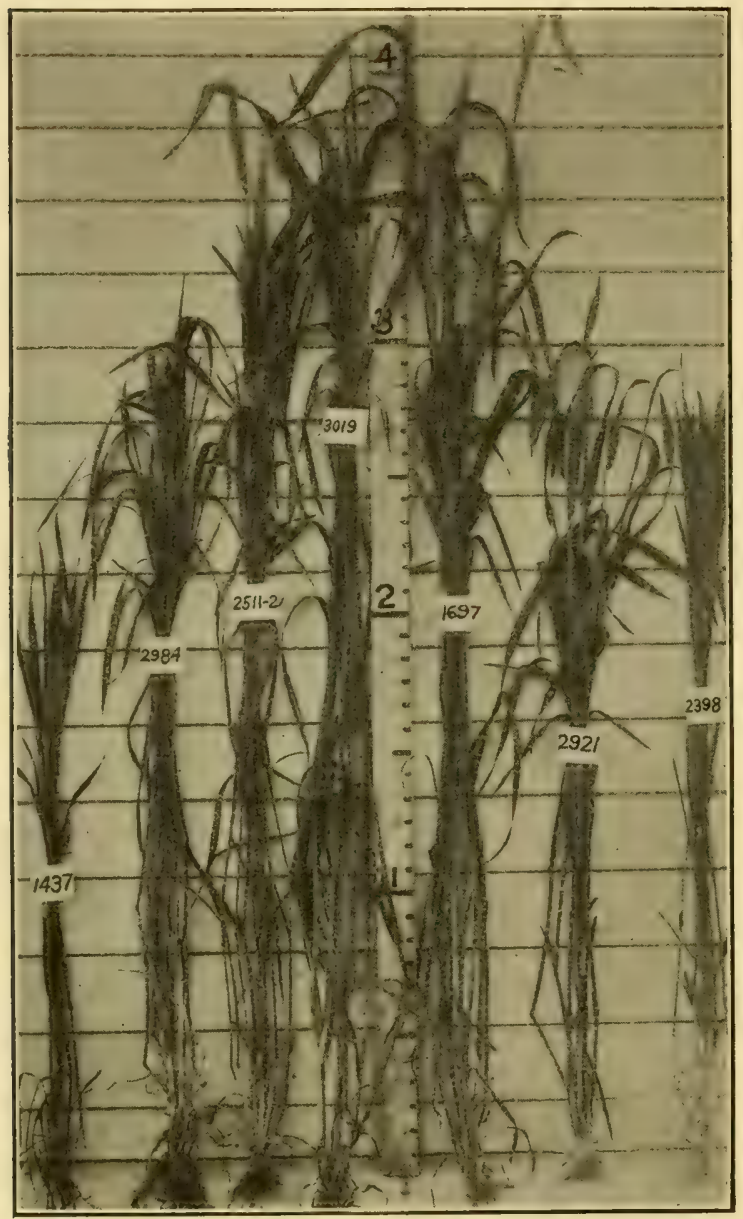

FIG. 7.-Representative plants of six additional varieties of wheat from uniform plats planted November 21, 1908, at Modesto, Cal., showing their comparative development on May 1, 1909: 1437, Crimean; 2984, Saumur de Mars; 2511-2, Abyssinian; 3019, Australian; 1697, Early Baart; 2921, Bolo Blanco; 2398, Galgalos. imported from Kansas and other States of the Middle West to blend with California wheat in the production of flour. From one-third to one-half of the blended wheat is made up of the Turkey variety. It is desired to make unnecessary this importation by the production in California of varieties equally as good. The flour value of wheat is judged by both the quantity and the quality of the product. In order to produce wheat of superior milling quality it is essential that varieties be grown which will give more and better protein to the acre. The quality of the protein depends on the quality of the gluten.

OTHER REQUISITES.

The ability of a variety to yield well under proper environment, the possession of a stiff or a weak straw, and the presence or absence of beards are all factors that need no further explanation, but must all be considered in the selection of a variety. Rust resistance is an important factor, especially in the coastal sections of California. Beardless varieties are often desired by the grower, as he may wish, on account of 
occasional seasonal disadvantages, to ('ut the crop for hay instead of allowing it to stand for grain. In such a case beardless wheats may he of more value than bearded ones, though this is not an important matter.

Seed Improvement by the Grower.

It is very important that the grain crowers of California practice better methods of seed selection.

SMALL COMPARED WITH IARGE SEFD.

The idea which prevails among some growers that small, light seed will produce as good crops as large, heavy seed is erroneous. In some instances, under very favorable conditions and if sown at the same rate to the acre according to weight, the small, light grains produce as heavy yields as the large, heavy grains, but the grain is of an inferior grade. The reason for the equality in yield to the acre is largely due to the fact that in the case of the seeding of small, light grains there are many more plants to a given area than when it is seeded with an equal weight of large, heavy grains of the same variety.

Ileavy, plump grain produces stronger and more vigorous plants than light, shriveled grain. The reason for this is that the plump grain contains a larger amount of food for the very young plant. The light, shriveled grain produces weak plants. This is a fact well understood by all who are endeavoring to improve their crops by careful and practical selection of seed.

It behooves the grain grower, then, to have at his disposal a good fanning mill with which he can grade his seed, blowing out all light, shriveled grain and separating the large grains from the small. Another advantage in the use of the fanning mill is the separation of the weed seed from the wheat.

THE SEED PLAT.

A practical method of improvement of seed, which should be used by every wheat producer in California, is what is known as the seed plat. This method is simple and easily applied. First, select from the general field at ripening time a large quantity of good heads of a single desirable form. Only heads from the best plants should be selected, and they should be from places where the soil is uniform with other parts of the field and not from an especially fertile spot or at the edge of the field. The heads should be thrashed by hand and the seed sown on well-prepared land free from volunteer grain. This crop should be harvested and thrashed separately from the main crop, care being taken that the machinery used is free from all other grains which might cause a mixture. The first portion thrashed should be rejected, as it is most likely to contain such a mixture. The grain from the seed plat should be used, as far as it will go, for the general crop the succeeding year. If there is a considerable acreage it may be necessary to continue the seed plat for a second year in order to obtain sufficient seed for the main crop. In order to effect permanent improvement the grower should make these 
selections of the best heads every year and sow them on the seed plat as suggested.

\section{TWO NEW VARIETIES OF WHEAT ADAPTED TO CALIFORNIA CONDITIONS.}

Of the many new varieties of wheat tested for yield and nitrogen content, the Chul (C. I. No. 2227) and the Fretes (G. I. No. 1596) have proved superior to the White Australian and Club varieties grown in the San Joaquin and Sacramento valleyss and are recommended for trial by farmers.

THE CIIUL VARIETY.

Origin and History.a.

Chul wheat (fig. 8) was received by the Office of Seed and Plant Introduction, December 1, 1902, from Dzhizak, a town about 100

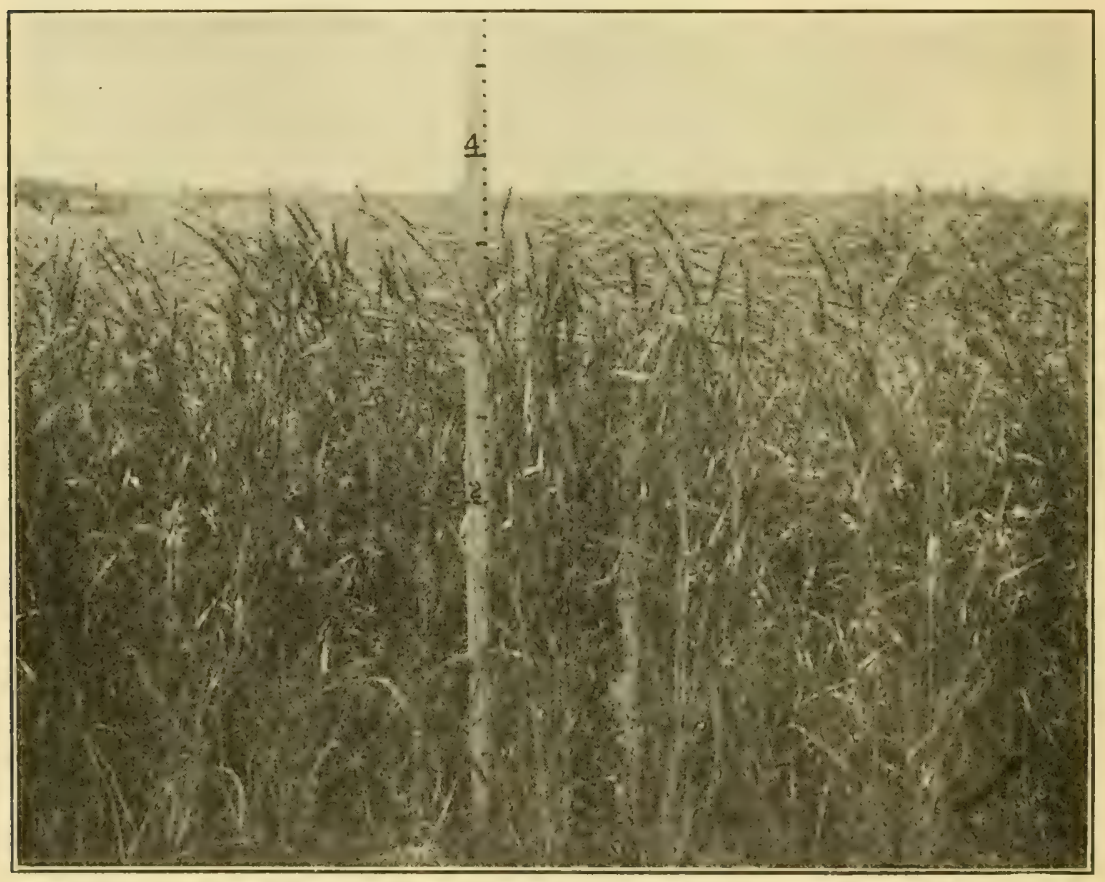

Fig. 8.-Chul wheat (G. I. No. 2227) growing at Modesto, Cal, in 1909. Yield to the acre, 53.33 bushels.

miles north of Samarkind, Turkestan. It was obtained through the Samarkand representatives of Mr. II. W. Durrschmidt by Mr. E. A. Bessey, of the Bureau of Plant Industry, August 30, 1902. The following notes concerning it were secured by Mr. Bessey:

Chul is grown on the steppes of Russia without irrigation. The grains are hard, but it is not a durum wheat. This variety yields two harvests a year, for it can be

a Bulletin 66, Bureau of Plant Industry, U. S. Dept. of Agriculture, 1905, p. 250. 178 
sown as either a winter or spring wheat. If the former, the harvest comes in July; if the latter, the harvest comes in september. If sown in the spring, it is sown just as soon as the snow melts. The spring sowing is most certain to yicld a good crop, for the fall sowing must depend upon the rather uncertain snows. This seed, however, is from the fall-sown seed. It is selected from over 1,000 poods offered for sale, and is remarkably clean and free from foreign seeds for this region.

\section{Introduction into Caijfornia.}

Seed of Chul wheat was first distributed by the United States Department of Agriculture in 1903 to a few farmers in California. Since 1903 small quantities have been sent out from time to time for the purpose of testing its adaptability. In 1904 and 1905 a variety test was commenced in Stanislaus and Sutter counties. This test was in direct charge of an officer of the Department, and has continued up to the present time. A limited distribution of improved seed of Californiagrown Chul wheat has been made to reliable farmers who are desirous of improving the yield and quality of their crop.

\section{DESCRIPTION}

The Chul is an early, erect, and vigorous variety which may be sown as late as February 15 and mature a good crop. It grows to a height of from $2 \frac{1}{2}$ to 4 feet and stools freely. The heads are medium long, tapering, and bearded. This variety has a very close-fitting chaff and does not shatter readily. As originally introduced it contained two forms, the one having white chaff, while the other produces red chaff. The kernels are large, long, and translucent in character. They are harder and more glutinous than those of the White Australian wheat. As originally introduced there were also two types of kernels, the one type being amber in color, the other dark red or reddish amber.

A separation of the red chaff form was made in 1905 at the Department's Plant Introduction Garden at Chico, Cal. Since that time the Department has separated the two forms represented by both colors in the original seed. This has been done by starting with single plants which were each characteristic of the form desired.

\section{Yielda ObTained.}

Very promising results have been reported from California to this Department by farmers who have given Chul wheat a trial. In variety tests made by the Department it has made a very favorable showing, excelling the commonly grown varieties in yield to the acre in some sections of the State.

The average yield to the acre of Chul wheat for 1907, 1908, and 1909 , as compared with the White Australian, is as follows: 
Miling Quality.

The milling quality of Chul wheat is superior to that of either the Club or the White Australian wheat, and for this reason this variety is of much value to the State of California. As previously shown, the common California wheats do not in themselves produce a high grade of flour.

The Department has made milling and baking tests of Chul and White Australian wheats grown at Modesto, Cal., in 1908. The results of this test indicate that Chul wheat produces from 100 pounds of grain about 10 pounds more flour than the Australian, and that it mills very much like Turkey wheat. The flour from the Chul is darker than that from either Australian or Fretes wheat, which in itself indicates that the Chul variety is stronger in gluten.

In the baking test Chul flour required more water to the loaf than that of the Australian variety and produced loaves of fair color and texture.

In August, 1909, the Oakdale Milling Company, Oakdale, Cal., made a milling test of Chul wheat, crop of 1909, grown at Modesto, Cal. This test gave 55 per cent wet gluten for the Chul, while similar tests showed only 10 to 38 per cent in the White Australian. Mr. Haslacher, manager of this company, was very enthusiastic over this variety and anxious that farmers should secure seed.

\section{THE FRETES VARIETY.}

\section{Origin and History.}

Seed of Fretes wheat (fig. 9) was received by the Office of Seed and Plant Introduction of the United States Department of Agriculture on September 26, 1901, from El-Outaya, Constantine, Algeria. It was obtained by Messrs. D. G. Fairchild and C. S. Scofield, who make the following notes on it:

This variety, sometimes called Freitiss, is one of the few soft wheats grown in Algeria. It is particularly noted for its early maturity and is often extensively planted in the Sahara Desert in seasons when the winter rains occur so late that the durum varieties usually grown would not have time to mature. When planted in November, as it is in Algeria, at the same time with durum varieties, it is said to ripen two months in advance of them. The seed obtained was grown on the rather salty desert sands in the vicinity of El-Outaya, north of Biskra, and watered with somewhat alkaline but still drinkable irrigation water. The variety is said to have originated from a shipment of Russian wheat which was made into Algeria at the time of a famine many years ago. Its early-maturing qualities attracted attention, and it has been cultivated in small quantities by the Arabs ever since. The seed obtained is from the farm of Mr. Charles B. des Places.

a Bulletin 66, Bureau of Plant Industry, U. S. Dept. of Agriculture, 1905, p. 151. 
Description.

Fretes wheat is an early, erect, vigorous variety and should be sown not later than December 15 . It grows to a height of from 3 to $4 \frac{1}{2}$ feet and stools well. The heads are of medium length, tapering, and bearded, with white chaff. The chaff of Fretes wheat does not inclose the grain as closely as that of the Chul variety, but still holds the seed fairly well. The kernels are medium large and plump, of medium length, and a reddish-amber color. They are softer than those of

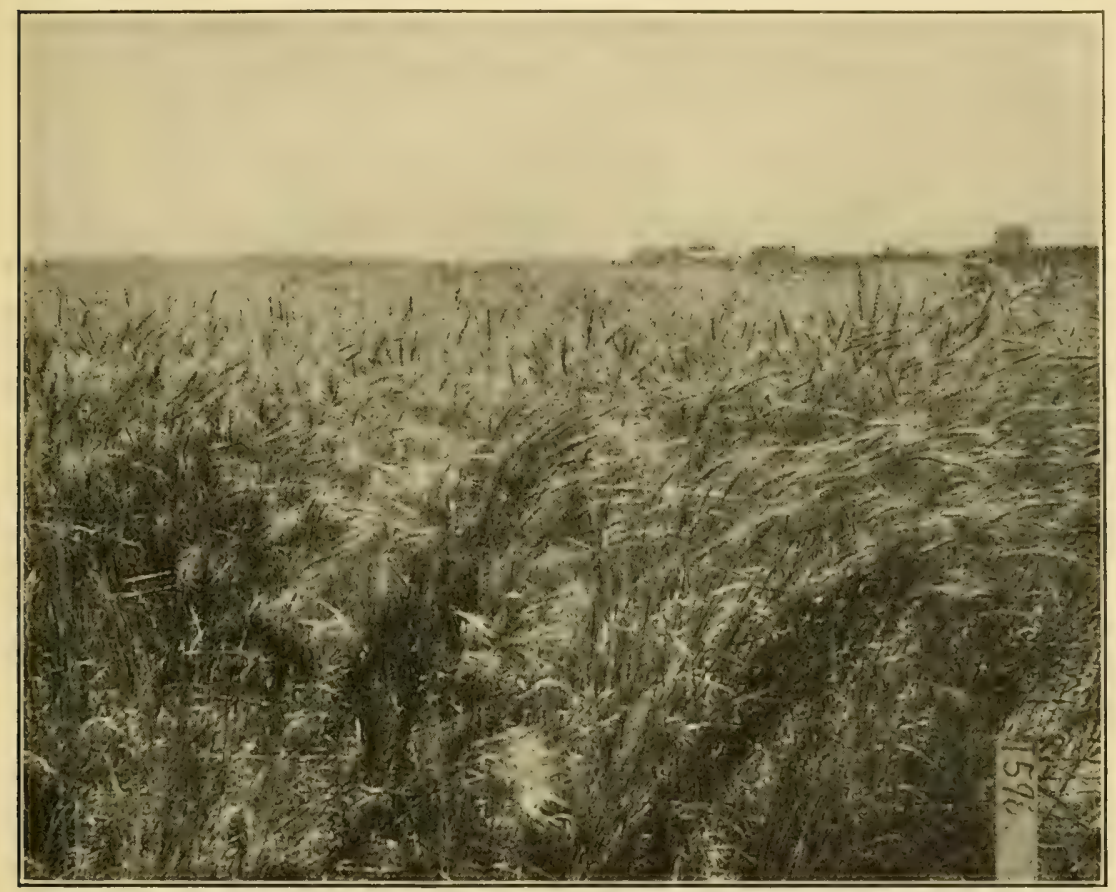

FiG. 9.-Fretes wheat (G. I. No. 1596) growing at Modesto, Cal., in 1909. Yield to the acre, 56 bus'.2cl:

Chul wheat. Single-plant selections have been made which are very promising.

Yields Obtained.

Fretes wheat was distributed by the Department to a few farmers in California as early as $\mathbf{1 9 0 2}$, and very good reports on its adaptability have been received. In 1904 and 1905 the Department commenced a variety test of this wheat on the experimental grounds in Sutter and Stanislaus counties. The observations made on the adaptability of this wheat to California conditions indicate that it will produce a larger yield to the acre than either the White Australian or Club wheats and that it is superior as a milling wheat. 
The average yield to the acre of Fretes wheat at Modesto, Cal., for 1907, 1908, and 1909, as compared with the White Australian (fig. 10), is as follows:

Fretes (G. 1. No. 1596) ......................... 46.5 bushels.

Australian (G. I. No. 3019)...................... . . 35.9 bushels.

\section{Milling Quality.}

Milling tests of this variety have been made by the United States Department of Agriculture and by the Oakrlale Milling Company. As a result of the test of the grain grown in California during 1908, made by the Department's laboratory at Fargo, N. Dak., we find this variety superior to the Club as a flour producer. It is also slightly superior to the White Australian. In this test it was discovered that

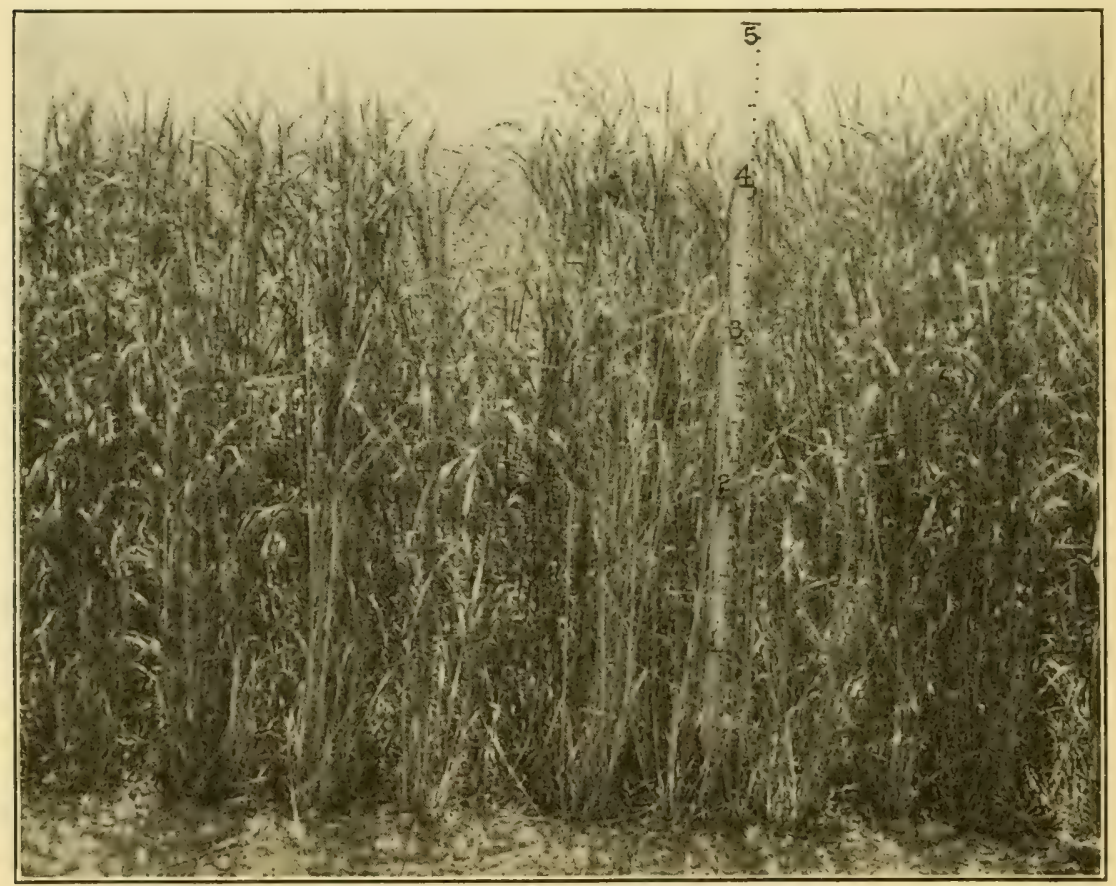

FIG. 10.-White Australian wheat (G. I. No. 3019) growing at Modesto, Cal, in 1909. Yield to the acre, 44 bushels.

there was a slight increase in the quantity of flour produced from 100 pounds of the Fretes over that produced from the same quantity of Australian wheat. It milled very much like the Australian. Ap)proximately the same quantity of water was required to produce a loaf of bread made from this flour as from the Australian. The loaves were slightly smaller but heavier than those baked from the Australian. The color and texture were fairly good. As with the Chul wheat, a 
milling test of the 1909 crop of the Fretes was made by the ()akdiale Milling Company, Oakdale, Cal. This test indicated that the Fretes milled easily. It also possessed a 40 per cent wet-gluten content as compared with the Australian samples received and tested by the company, which contained from 10 to 38 per cent of wet gluten.

\section{PURE SEED OF THE CHUL AND FRETES VARIETIES.}

From the foregoing facts there can be little doubt that the improved types of the Chul and Fretes rarieties are of great ralue to California. Much care, however, should be exercised by the growers in securing pure seed.

It is reported that Chul wheat is being grown in quantity by a few farmers in the Sacramento Valley from seed introduced into California by the United States Department of Agriculture in 1903. It is also reported that this wheat is used to good effect in blending with the common wheats in the production of flour. Samples of the 1909 (rop, which have been received, show that this wheat is mixed with other varieties. This is probably due to lack of care on the part of growers in keeping the variety pure. This mixture is an inferior grade of seed and is not desirable for the farmer wishing to start with pure seed of the Chul variety.

The Office of Grain Investigations of the Bureau of Plant Industry can usually supply small quantities of pure seed of these and other varieties.

\section{PROTEIN CONTENT AS AFFECTED BY TIME OF SEEDING.}

Observations in California indicate that the length of the growing and fruiting periods of a variety of wheat controls, to a considerable degree, the percentage of protein contained. Long growing and fruiting periods produce grains lower in protein content than short growing and fruiting periods. An effort was made during the past year to determine the effect of the length of these periods upon the protein content of the Chul and Fretes varieties sown early and late. The results obtained are given in Table III.

TABLE III.-Eiffect of the length of groming and fruiting periods on the protein content. of the Chul and Fretes wheat varieties.

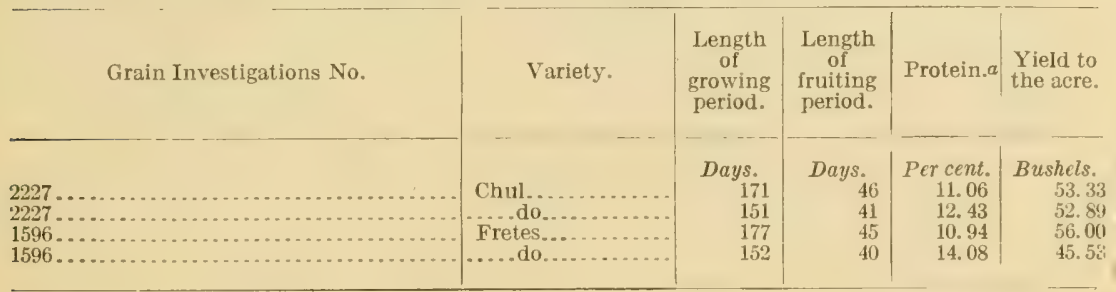

a The pereentages of protein were obtained by multiplying the percentage of nitrogen by 5.7 . 
$\Lambda$ s indicated in Table III, a higher percentage of protein is produced in a short growing and fruiting period than in a long period. The yields of Chul wheat are nearly equal, while there is some difference in those of the Fretes. In order to shorten the periods and produce grain rich in protein, the seeding should be done as late as possible in the fall. The Chul variety is especially adapted to late seeding for the reason that it is a vigorous grower and ripens early. Excellent results have been obtained from the Chul when sown as late as February 25, but usually the seeding should be done between November 15 and December 25. The Fretes seed should be in the ground by December 15 . The above dates refer to the time of seeding in the San Joaquin Valley. These wheats may be sown a month later in the Sacramento Valley and still give good results under ordinary conditions.

\section{SUMIMARY.}

Wheat yields in California are low and the quality poor. Experiments have been conducted to discover the causes and remedies. Two remedies are proposed in this bulletin, namely, better cultivation methods and better varieties.

The cultivation methods commonly practiced by the wheat farmers of California are unsatisfactory. They consist in the continuous cropping of wheat and barley upon soil which receives only a very shallow cultivation.

The farmer removes the plant food from the soil without adding anything to take its place. This is resulting in many localities in a depleted condition of the soil and in unprofitable crops.

When wheat was at first produced, good crops were secured by very shallow plowing, broadcasting the seed, and harrowing it into the soil. Very little attempt was made to secure pure seed or to practice the careful grading of wheat.

Some important changes have taken place, among which are (1) the replacing of the header and stationary thrasher by the combined harvester and (2) the practice of summer-fallowing the land. A reduced size of farms and an increased depth of plowing occur in individual instances.

In many sections of the State there has resulted from the original methods a soil depleted in humus and nitrates and foul with weeds, which fails to produce profitable crops. There are three chief requirements in restoring the production of profitable crops. These are (1) smaller farms, personally supervised; (2) improved methods, including deeper plowing, increasing the humus and nitrates of the soil, and cleaning the land of weeds; and (3) the development of better varieties. 
Soil humus and nitrates are easily increased by turning under green-manure crops. Crops proving to be of value as green manure are Canalian field peas and Abruzzes rye. Green-manure crops should not be sown later than December 15. The stubble should be clouble-disked immediately after the wheat crop is harvested, followed by a shallow plowing as early as possible in the fall. These crops should be turned under during early March before the soil is too dry for deep plowing, which is necessary in order to get the growing peas and rye well under, after which the soil should be harrowed immediately.

The good effect of deep plowing and green manuring is proved in actual experiment by increased yields and profits.

A method of cultivation whereby the land mav be cleaned of weeds should be employed.

$\Lambda$ large number of wheat varieties have been tested in California in an attempt to find better ones. Factors entering into the selection of varieties for California are the climate and soil of the focality where the variety is to be tested, the habit of growth of the variety, its nonshattering character, milling quality, yield, strength of straw, the presence or absence of beards, and rust resistance.

It is important that grain growers practice better methods of seed selection. The seed should be graded with a fanning mill. A practical method of improvement is the use of what is known as the "seed plat."

The Chul and Fretes wheats are new varieties adapted to California conditions. In some sections of the State these wheats have excelled the commonly grown varieties in yield to the acre.

Milling and baking tests of the Chul and Fretes varieties have been made which indicate that they are superior to Australian and Club wheats in these respects.

Much care should be exercised by the growers in securing pure seed of these wheats.

Observations indicate that the length of the growing and fruiting periods of a variety of wheat controls to a considerable degree the percentage of protein contained. Short growing and fruiting periods produce grain with a high percentage of protein.

The Chul and Fretes varieties are adapted to comparatively late sceding, which is favorable to a high percentage of protein in the grain produced. 



\section{INDEX.}

Abruzzes rye. See Rye, Abruzzes.

I'age.

Algeria, original home of Fretes wheat.......................... 26

Allora wheat. See Wheat, Allora.

Australian wheat. See Wheat, Australian.

Beans, horse, value as green-manure crop on wheat lands in California...... . 15. 16

Beardless wheat. See Wheat, beardless.

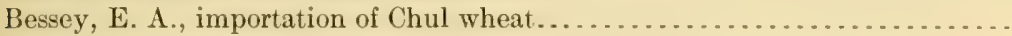

Blé Noir. See Wheat, Blé Noir.

Bolo Blanco wheat. See Wheat, Bolo Blanco.

California Gem wheat. See Wheat, California Gem.

wheat. See Wheat, California.

Canadian field peas. See Peas, Canadian field.

Cap Sheaf wheat. See Wheat, Cap Sheaf.

Chiddam wheat. See Wheat, Chiddam.

Chul wheat. See Wheat, Chul.

Climate, importance in selecting wheat varieties for California.............

Club wheat. See Wheat, Club.

Crimean wheat. See Wheat, Crimean.

Dietz Amber wheat. See Wheat, Dietz Amber.

Early Baart wheat. See Wheat, Early Baart.

Erivan wheat. See Wheat, Erivan.

Fairchild, D. G., importation of Fretes wheat seed.................... 26

Fallow, summer, effect on wheat yield, experiments in California......9, 16,17,30

Fanning mill. See Mill, fanning.

Farms, owners, personal supervision, remedy for faulty methods of wheat culture in California................................... 10-11

small, remedy for faulty methods of wheat culture in California...... 10-11

Filipino wheat. See Wheat, Filipino.

Flour, Chul, Club, Fretes, and White Australian wheats, baking tests.... 26, 28, 31 value of wheat, relation of protein content.................... 22

Freitiss, name for Fretes wheat................................ 26

Fretes wheat. See Wheat, Fretes.

Galgalos wheat. See Wheat, Galgalos.

Gluten, content in wheat varieties, value $22,26,29$

relation to yield and quality of protein in wheat.................. 22

Grain, production of crops, requirements in California............. 10-24, 30

Green manure. See Manure, green.

Harvester, combined, replacing of header and stationary thrasher, effect on

wheat crop in California............................. $8-9,30$

Header, replacing by combined harvester, effect on wheat crop in ('alifornia . 8-9,30

Heads, wheat, nonshattering, desirable quality in California . . . . . . . . . . 21, 31

Hilgard, E. W., citation of Wollny on the effect of humus on soil temperature. . 9

Horse beans. See Beans, horse. 
Page.

Humus, addition to soil by green-manure crops..................... 12-15

deficiency in wheat lands, California, causes........... . . . . . . . 9-10

effects on soil..................................... 9,12

improvement of sandy lands............................ 12

Introduction to bulletin.................................... $7-8$

Kharkof wheat. See Wheat, Kharkof.

Kubanka wheat. See Wheat, Kubanka.

Lands, wheat, California, cleaning of weeds, directions................. 18-19

Legumes. See Manure, green, and nitrogen.

Manure, green crops, California, effect on yield of wheat............ 15-18,31

seeding and handling, directions....... 12-18, 31

Marouani wheat. See Wheat, Marouani.

time and method of handling........... $13-15$

Medeah wheat. See Wheat, Medeah.

Mill, fanning, necessity for cleaning and grading wheat............... 23, 31

Minnesota No, 66 wheat, See Wheat, Minnesota No. 66.

163 wheat. See Wheat, Minnesota No. 163.

Modesto, Cal., experiments with deep plowing and green manuring......... 15-18

Nitrates, addition to soil by leguminous crops....................... 13

deficiency in wheat lands of California.................... 9

soil, necessity in wheat production...................... . 9-10

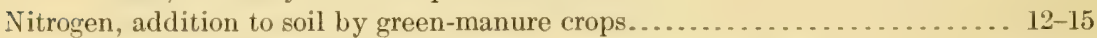

Oakdale Milling Company, milling tests of wheat varieties, 1909 . . . . . . 26, 28-29

Peas and rye, use as green-manure crops......................... 13-15

Canadian field, value as green-manure crop............... 13, 16, 31

seed, quantity per acre for green manure..................... 13

Plowing, deep, effect on yield of wheat in California............... . 15-18, 31

wheat lands, necessity; importance, and results...... 11-12, 15-18

Propo wheat. See Wheat, Propo.

Protein, content in wheat, effect of time of seeding in California . . . . . . 29 29-30, 31

relation to flour value..................... 22

production per acre in wheat, relation of quality of gluten........ 22

Purple Straw wheat. See Wheat, Purple Straw.

Rust, resistance of wheat, important quality in California.............. 22

Rye, Abruzzes, value as green-manure crop.................... 13, 31

and peas, use as green-manure crops on wheat lands, California...... 13-15

vetch, use as green-manure crops on wheat lands, California . . . . . . 16

seed, quantity per acre for green manure...................... 13

Sacramento Valley, California, green-manure crops adaptable............ 13

wheat variety tests..................... 19

San Joaquin Valley, Califonia, green-manure crops adaptable.............. 13

wheat variety tests...................... 19

Saumur de Mars wheat. See Wheat, Saumur de Mars.

Scofield, C. S., importation of Fretes wheat seed ...................... 26

Seed, peas, quantity per acre for green manure ..................... 13

rye, quantity per acre for green manure ........................ 13

selection, wheat, importance in California.................... 23-24

wheat, grading necessary in careful selection..................... 23

improvement by better methods of selection............... 23

large and small, comparative value.................... 23

plat, directions for planting and use................. 23-24

purity, importance to growers in California.................. 29 
Seeding, peas and rye, for green-manure crop), directions. ............. 13-15

wheat, time, effect on protein content in California......... 29-30,31

Soil, California wheat lands, deficiency in humus and nitrates............ 9-10

importance in selecting wheat varieties for California.............. 20

improvement by addition of humus and nitrogen ................ 12-15

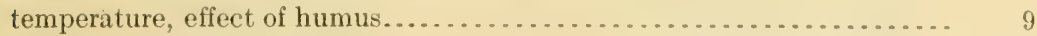

Sonora wheat. See Wheat, Sonora.

Summer-fallow. See Fallow, summer.

Temperature, soil. See Soil, temperature.

Tenants, cropping methods injurious to wheat farn:s in ('alifornia..........

Theiss wheat. See Wheat, Theiss.

Thrasher, stationary, replacing by combined harvester, effect on wheat crop in

California.

8,30

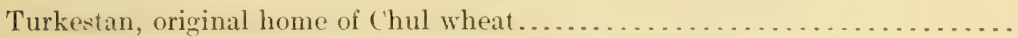

Turkey wheat. See Wheat, Turkey.

Varieties, wheat, testing and selection for California................. 19-23

Velvet Don wheat. See Wheat, Velvet Don.

Vetch and rye as green-manure crops for wheat lands, California. ........ 16

Washington Bluestem wheat. See Wheat, Washington Bluestem.

Weeds, bad effect on wheat crop in California. . . . . . . . . . . . . . . . . 10

wheat lands, California, causes and remedies................ 10, 18-19

Wheit, Allora, test in California........................... 20

Australian, test in ('alifornia............................

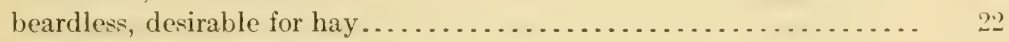

Blé Noir, test in California............................ 20

Bolo Blanco, test in California. . . . . . . . . . . . . . . . . . . 20, 22

California, damage by weeds. .......................... 10, 18

Gem, test in California...................... 20

requirements for profitable production . . . . . . . . . . . . 10-24

variety tests............................ 19-20, 25-27

yields, decrease, causes and remedies............. 8-19

Cap Sheaf, test in California. . . . . . . . . . . . . . . . . . . . 20

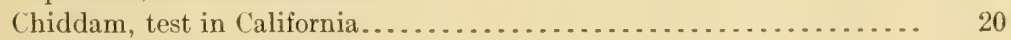

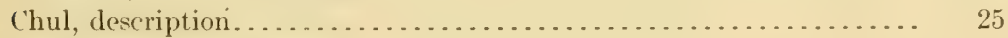

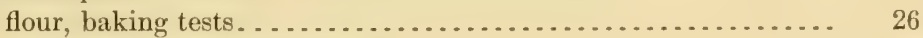

introduction into California......................... 25

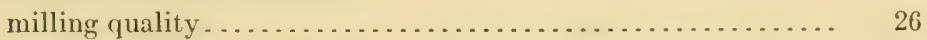

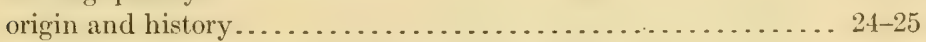

seed, purity, importance to growers in California............. 29

separation of variety into two forms. . . . . . . . . . . . . . . 25

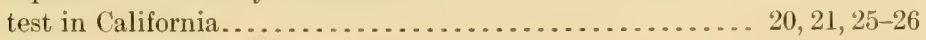

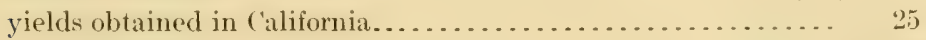

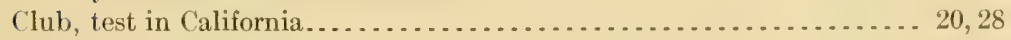

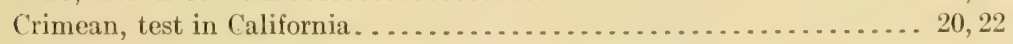

cultivation, California, changes from original methods........... 8-9

cost per acre, comparison of methods......... 17-18

directions for cleaning land of weeds......... 18-19

faulty methods and results............... 8 8-10

original methods .................... 8

past and present methods, bad results...... 9-10

smaller farms and personal supervision by owners, importance................... 10-11 
Wheat, culture, improved methods...................... 11-19

development of better varieties for California........ . . . . . . . . . . 19-24

Dietz Amber, test in California.............................. 20

earliness, importance in checking weeds in California........... 21

Early Bart, test in California............................ 20, 22

Erivan, test in California............................ 20,21

Filipino, test in California................................. 20

flour, value, relation of protein content....................... 22

Fretes, description....................................... 27

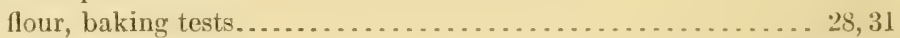

milling quality .............................. . $28-29,31$

origin and history................................. 26

seed, purity, importance to growers in California... . . . . . . . 29

test in California............................ 20, 21, 27-29

yields obtained in California....................... 27-28

Galgalos, test in California........................... . . 20, 22

gluten content, value...................................... 22, 29

grading, necessity of fanning mill............................ 31

habits of growth desirable for California................... 21

heads, nonshattering, desirable character for California .......... 21

Kharkof, test in California............................. 20

Kubanka, test in California............................. 20

lands, California, effect of deep plowing and green manuring. . . . . . . 15-18 green-manure crops, time and method of handling... 13-15 improvement by green-manure crops........... 12-18

Marouani, test in California........................... 20

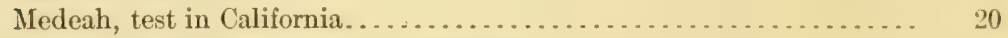

milling quality, importance in California.................. 22

Minnesota No.66, test in California......................... 20

163 , test in California ......................... 20

profits, effect of green-manure crops and deep plowing in California... 17-18

Propo, test in California............................. 20

protein content, effect of time of seeding in California.......... 29-30,31

relation to flour value..................... 22

short season and late seeding favorable in Califor-

nia............................... 29-30, 31

Purple Straw, test in California....................... 20

rust resistance, importance in California . . . . . . . . . . . . . . . 22

Saumur de Mars, test in California............. . . . . . . . . . . 20, 22

seed selection, importance in California................... . 23-24

See also Seed.

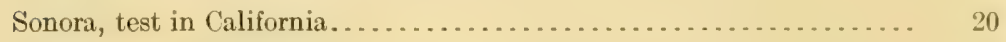

Theiss, test in California.............................. 20

Turkey, blending with California wheats in milling......... 7,22

test in California.................................... 0,21

varieties; new, adapted to California...................... 24-30

selection for California. . . . . . . . . . . . . . . . . . . . . . 20 20 23

testing in California . . . . . . . . . . . . . . . . . 19-20, 25, 27

Velvet Don, test in California. ......................... 20

Washington Bluestem, test in California................... 20

White Australian, milling quality, comparison with Chul and Fretes

wheats. ............................. 26, 28 
l'age.

Wheat, White Australian, yield, comparison with Chul and Fretes wheats in

California................................... 25, 27-28

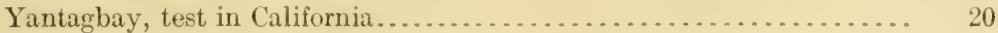

Yellow Gharnovka, test in California....................... 20

yield, California, decrease, causes and remedies................. 8-19

effect of green-manure crops and deep plowing..... 15-18

White Australian wheat. See Wheat, White Australian.

Wollny, statement of effect of humus on soil temperature ............... 9

Yantagbay wheat. Sce Wheat, Yantagbay.

Yellow Gharnovka wheat. See Wheat, Yellow Gharnovka.

Yield, wheat. Sce Wheat, yield.

178 

No. 96. Tobacco Breeding. 1907. Price, 15 cents,

97. Seeds and Plants Imported. Inventory. No.11. 1907. Price, 15 cents.

98. Soy Bean Varieties. 1907. Price, 15 cents.

99. Quick Method for Determination of Moisture in Grain. 1907. Price, 5 cents.

101. Contents of and Index to Bulletins Nos. 1 to 100. 1907. Price, 15 cents.

102. Miscellaneous Papers. 1907. Price, 15 cents.

103. Dry Farming in the Great Basin. 1907. Price, 10 cents

104. The Use of Feldspathic Rocks as Fertilizers. 1907. Price, 5 cents.

105. Relation of Leaf to Burning Qualities of Tobaceo. 1907. Price, 10 cents.

106. Seeds and Plants Imported. Inventory No. 12. 1907." Price, 15 cents.

107. American Root Drugs. 1907. Price, 15 cents.

108. The Cold Storage of Small Fruits. 1907... Price, 15 cents.

109. American Varieties of Garden Beans. 1907. Price, 25 cents.

110. Cranberry Diseases. 1907. Price, 20 cents.

112. Suprarenal Glands in Physiological Testing of Drug Plants. 1907. Price, 10 cents.

113. Tolerance of Various Plants for Salts in Alkali Soils. 1907. Price, 5 cents.

114. Sap-Rot and Other Diseases of the Red Gum. 1907. Price, 15 cents.

115. Disinfection of Sewage for Protection of Public Water Supplies. 1907. Price, 10 cents.

116. The Tuna as Food for Man. 1907: Price, 25 cents

117. The Reseeding of Depleted Range and Native Pastures. 1907. Price, 10 cents.

118. Peruvian Alfalfa. 1907. Price, 10 cents.

119. The Mulberry and Other Silkworm Food Plants. 1907. Price, 10 cents.

120. Production of Easter Lily Bulbs in the United States. 1908. Price, 10 cents.

121. Miscellaneous Papers. 1908. Price, 15 cents.

122. Curly-Top, a Disease of Sugar Beets. 1908. Price, 15 eents.

123. The Decay of Oranges in Transit from California. 1908. Price, 20 cents.

124. The Prickly Pear as a Farm Crop. 1908. Price, 10 cents,

125. Dry-Land Olive Culture in Northern Africa. 1908. Price, 10 cents.

126. Nomenclature of the Pear. 1908. Price, 30 cents.

127. The Improvement of Mountain Meadows. 19j8. Price, 10 cents.

128. Egyptian Cotton in the Southwestern United States. 1908. Price, 15 cents.

129. Barium, a Cause of the Loco-Weed Disease. 1908. Price, 10 cents.

130. Dry-Land Agriculture. 1908. Price; 10 cents.

131. Miscellaneous Papers. 1908. Price, 10 cents.

133. Peach Kernels, etc, as By-Products of the Fruit Industry, 1908. Price 5 cents. 134. Influence of Soluble Salts upon Leaf Structure and Transpiration of Wheat, Oats, and Barley.
1908 . Price, 5 cents.

135. Orchard Fruits in Virginia and the South Atlantic States. 1908. Price, 23 cents.

136. Methods and Causes of Evolution. 1908. Price, 10 cents.

137. Seeds and Plants Imported. Inventory No. 14. 1909. Price, 10 cents.

138. Production of Cigar-Wrapper Tobacco in Connecticut Valley. 1908. Price, 15 cents.

139. American Medicinal Barks. 1909. Price, 15 cents.

140. "Spineless" Prickly Pears. 1909. Price, 10 cents.

141. Miscellaneous Papers. 1909. Price, 10 cents.

142. Seeds and Plants Imported. Inventory No, 15. 1909. Price, 10 cents.

143. Principles and Practical Methods of Curing Tobacco. 1909. Price, 10 cents.

144. Apple Blotch, a Serious Disease of Southern Orchards. 1909. Price, 15 cents.

145. Vegetation Affected by Agriculture in Central America. 1909. Price, 15 cents.

146. The Superiority of Line Breeding over Narrow Breeding. 1909. Price, 10 cents.

147. Suppressed and Intensified Characters in Cotton Hybrids. 1909. Price, 5 cents.

143. Seeds and Plants Imported. Inventory No.16. 1909.' Price, 10 cents.

149. Diseases of Deciduous Forest Trees. 1909. Price, 15 cents.

150. Wild Alfalfas and Clovers of Siberia. 1909. Price, 10 cents

151. Fruits Recommended for Cultivation. 1909. Price, 15 cents.

152. Loose Smuts of Barley, and Wheat. 1909. Price, 15 cents.

153. Seeds and Plants Imported. Inventory No. 17. 1909. Price, 10 cents.

154. Farm Water Supplies of Minnesota. 1909. Price, 15 cents.

155. Control of Black-Rot of the Grape. 1909. Price, 15 cents.

156. A Study of Diversity in Egyptian Cotton. 1909. Price, 15 cents.

157. The Truckee-Carson Experiment Farm. 1909. Price, 10 cents.

158. The Root-Rot of Tobacco Caused by Thielavia Basicola. 1909: Price, 15 cents:

159. Local Adjustment of Cotton Varieties. 1909. Price, 10 cents.

160. Italian Lemons and Their By-Products. 1909. Price, 15 cents.

161. A New Type of Indian Corn from China, 1909. Price, 10 cents.

162. Seeds and Plants Imported. Inventory No. 18. 1909, Price, 10 cents.

163. Varieties of American Upland Cotton. 1910. Price, 25 cents.

164. Promising Root Crops for the South. 1910. Price, 10 cents.

165. A pplication of Principles of Heredity to Plant Breeding. 1910. Price, 10 cents.

166. The Mistletoe Pest in the Southwest. 1910. Price, 10 cents.

167. New Methods of Plant Breeding, 1910. - Price, 20 cents.

168. Seeds and Plants Imported. Inventory No. 19. 1909. Price, 5 cents.

169. Variegated Alfalfa. 1910. Price, 10 cents.

170. Traction Plowing. 1910. Price, 10 cents.

171. Some Fungous Diseases of Economic Importance. [In press.]

172. Grape Investigations in Vinifera Regions, [In press.]

173. Seasonal Nitrification as Influenced by Crops and Tillage. 1910. Price, 10 cents.

174. The Control of Peach Brown-Rot and Scab. 1910. Price, 10 cents.

175. The History and Distribution of Sorghum. 1910. Price, 10 cents.

176. Seeds and Plants Imported. Inventory No, 20. 1910. Price, 5 cents.

177. A Protected Stock Range in Arizona. 1910. Price, 15 cents. 





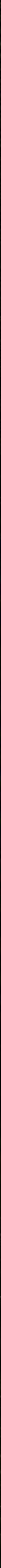

